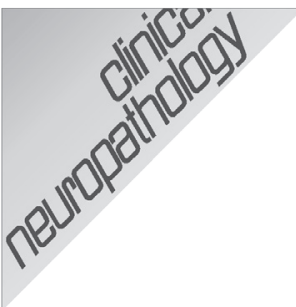

๑2016 Dustri-Verlag Dr. K. Feistle ISSN 0722-5091

DOI 10.5414/NP300902 e-pub: December 28, 2015

Key words

spinal muscular atrophy - SMARD-diaphragmatic palsy - respiratory distress - peripheral neuropathy
Received

July 14, 2015;

accepted in revised form

September 27, 2015

Correspondence to

Susana Teijeira, PhD Institute of Biomedical Research of Ourense Pontevedra Vigo (IBI), Complexo Hospitalario Universitario de Vigo (CHUVI), Biomedical Research Unit, Hospital Álvaro Cunqueiro, 36312 Vigo, Spain susana.teijeira. bautista@sergas.es

\title{
Spinal muscular atrophy with respiratory distress type 1 (SMARD1)
}

\author{
Report of a Spanish case with extended clinicopathological follow-up
}

\author{
Beatriz San Millan ${ }^{1,4}$, Jose M. Fernandez ${ }^{2,4}$, Carmen Navarro ${ }^{1,4}$, Alfredo Reparaz ${ }^{3}$, \\ and Susana Teijeira ${ }^{1,4}$ \\ ${ }^{1}$ Department of Pathology, ${ }^{2}$ Department of Clinical Neurophysiology, ${ }^{3}$ Neonatal \\ Intensive Care Unit; Complexo Hospitalario Universitario de Vigo (CHUVI), and \\ ${ }^{4}$ Institute of Biomedical Research of Ourense·Pontevedra·Vigo (IBI), Vigo, Spain
}

Abstract. Background: Spinal muscular atrophy with respiratory distress type 1 (SMARD1) is a clinically and genetically distinct and uncommon variant of SMA that results from irreversible degeneration of $\alpha$-motor neurons in the anterior horns of the spinal cord and in ganglion cells on the spinal root ganglia. Aims: To describe the clinical, electrophysiological, neuropathological, and genetic findings, at different stages from birth to death, of a Spanish child diagnosed with SMARD1. Patient and methods: We report the case of a 3-monthold girl with severe respiratory insufficiency and, later, intense hypotonia. Paraclinical tests included biochemistry, chest X-ray, and electrophysiological studies, among others. Muscle and nerve biopsies were performed at 5 and 10 months and studied under light and electron microscopy. Post-mortem examination and genetic investigations were performed. Results: Pre- and post-mortem histopathological findings demonstrated the disease progression over time. Muscle biopsy at 5 months of age was normal, however a marked neurogenic atrophy was present in post-mortem samples. Peripheral motor and sensory nerves were severely involved likely due to a primary axonal disorder. Automatic sequencing of $I G H M B P 2$ revealed a compound heterozygous mutation. Conclusions: The diagnosis of SMARD1 should be considered in children with early respiratory insufficiency or in cases of atypical SMA. Direct sequencing of the IGHMBP2 gene should be performed.

\section{Introduction}

Spinal muscular atrophy with respiratory distress type 1 (SMARD1, OMIM \#604320), also called diaphragmatic SMA, distal he- reditary motor neuropathy type VI, or severe infantile axonal neuropathy with respiratory failure, is a clinically and genetically distinct form of spinal muscular atrophy type 1 (SMA1), first described by Mellins et al. in 1974 [1]. This is an extremely infrequent disease of autosomal recessive inheritance that results from irreversible degeneration of $\alpha$-motor neurons in the anterior horns of the spinal cord and ganglion cells in the dorsal root ganglia (DRG). It leads to severe muscular atrophy of phrenic predominance causing early respiratory distress. Distal limb weakness subsequently occurs, with severe generalized hypotonia, areflexia, and progressive peripheral neuropathy. Prognosis is very poor and patients die of respiratory failure at an early age. The IGHMBP2 gene, responsible for SMARD1, is located on chromosome 11q13, which encodes the immunoglobulin mu-binding protein $2[2,3,4$, $5,6,7,8,9]$.

Here we describe the clinical, electrophysiological and neuropathological findings, at different stages from birth to death, and the genetic studies of a Spanish child diagnosed with SMARD1 and a mutation in IGHMBP2 [4]. Prenatal diagnosis was performed in a second pregnancy of the mother by chorionic villous biopsy at 11 weeks' gestation. To our knowledge, this is one of the few cases with sequential examinations during life and post-mortem studies.

SMARD1 should be considered as a differential diagnosis in every newborn with respiratory distress and diaphragmatic paralysis, even prior to muscle weakness onset. 
Table 1. Motor neurography performed in several nerves at 4, 11, and 16 months of age.

\begin{tabular}{|c|c|c|c|c|}
\hline Nerve & $\begin{array}{c}\text { Distal latency } \\
\text { (ms) }\end{array}$ & $\begin{array}{c}\text { Amplitude } \\
(\mu \mathrm{V})\end{array}$ & $\begin{array}{l}\mathrm{MCV} \\
(\mathrm{m} / \mathrm{s})\end{array}$ & F-Lat \\
\hline \multicolumn{5}{|l|}{ At 4 months of age } \\
\hline Median & 3.0 & 2.6 & 19.0 & 18.0 \\
\hline Right peroneal & 5.2 & 0.3 & 14.0 & Absent \\
\hline Left tibial & 5.0 & 1.2 & 13.0 & 45.7 \\
\hline Right phrenic & 5.5 & 0.1 & ND & ND \\
\hline Left phrenic & 5.4 & 0.1 & ND & ND \\
\hline \multicolumn{5}{|c|}{ At 11 months of age } \\
\hline Median & 3.4 & 0.6 & 16 & 18.8 \\
\hline Peroneal & 4.3 & 0.2 & 13 & ND \\
\hline Tibialis & 5.6 & 0.3 & 15 & ND \\
\hline Facial & 4.3 & 0.3 & ND & ND \\
\hline Axilaris & 2.7 & 0.5 & ND & ND \\
\hline \multicolumn{5}{|c|}{ At 16 months of age } \\
\hline Median & 4.9 & 0.1 & 17 & ND \\
\hline Facial & 3.9 & 0.8 & ND & ND \\
\hline Axilaris & 4.8 & 1.2 & ND & ND \\
\hline
\end{tabular}

$\mathrm{MCV}=$ motor conduction velocity $; \mathrm{F}$-Lat $=\mathrm{F}$-wave latency $\mathrm{ND}=$ not done

\section{Case report}

A 3-month-old girl was admitted to the hospital with respiratory difficulty, tachypnea and forced respiration with retractions, which had been noticed in an ordinary pediatric control. She was the first child of unrelated, young, and healthy parents without familial history of neuromuscular disorders or sudden infant death syndrome. The baby had been born by caesarean section at 34 weeks gestation due to intrauterine growth retardation (IUGR), decreased fetal movements, and abruptio placentae diagnoses. She weighed $1,550 \mathrm{~g}$ at birth $\left(<10^{\text {th }}\right.$ percentile), with an Apgar score of 8/10, and presented neonatal respiratory distress immediately after birth, requiring mechanical ventilation and pulmonary surfactants for 3 days.

On admission at 3 months, pulmonary auscultation revealed severe bilateral hypoventilation with crepitus. Chest X-ray suggested bronchiolitis and she received corticoids and oxygen without improvement. The disease progressed to severe respiratory insufficiency, requiring mechanical ventilation. Repeated efforts to wean her from ventilator resulted unsuccessful.

Limb weakness with distal to proximal progression appeared shortly after the onset of respiratory insufficiency, with marked generalized hypotonia, areflexia, bilateral equin- ovarus foot deformities, and Achilles contractures. Tongue fasciculations were absent.

Serologic and biochemical parameters, including creatinine kinase levels and cerebrospinal fluid analyses were normal. Results from other tests performed for infective and metabolic conditions were unrevealing.

On electrophysiological examination, sensory potentials were abolished in the lower limbs and fingers. The only recordable potential was that of the median nerve (amplitude $2.6 \mu \mathrm{V}, \mathrm{SCV} 21 \mathrm{~m} / \mathrm{s}$ ) (Table 1). Concentric needle examination revealed severe partial denervation in all examined muscles of the upper and lower limbs. Complete denervation of the left hemidiaphragm was demonstrated.

Electroencephalogram, brain magnetic resonance imaging (MRI), and cardiologic studies did not show abnormalities. Genetic analysis for Survival Motor Neuron (SMNI) gene was negative. Electron microscopy of skin and biochemical assays in cultured fibroblasts ruled out metachromatic and globoid cell leukodystrophies.

Muscle and nerve biopsies were performed at 5 and 10 months of age. At 5 months muscle biopsy was nearly normal. However, sural nerve biopsy at that age demonstrated significant decrease in myelinated fiber density (Figure 1A) with no evidence of inflammation. At electron microscopy examination, no onion bulbs or axonal cluster formation were present. Microtubules and neurofilaments were normal. Giant axons, metachromasia, or lysosomal storage were absent (Figure 1B).

Electrophysiological examinations at 11 months of age demonstrated complete denervation in the most distal muscles (tibialis anterior, gastrocnemius, and foot muscles) and severely reduced interference pattern in the most proximal ones (vastus lateralis, deltoid, and facial muscles) (Table 1). At that age, marked atrophy of both type I and type II fibers was found in muscle biopsy (Figure 1C) with fibers showing prominent nuclei and increased oxidative activity, clearly demonstrative of a neurogenic process (Figure 1D) showing features of immature fetal phenotype (Figure 2).

Despite therapeutic efforts, the condition of the child rapidly deteriorated, resulting in complete paralysis of limbs and trunk. In the 

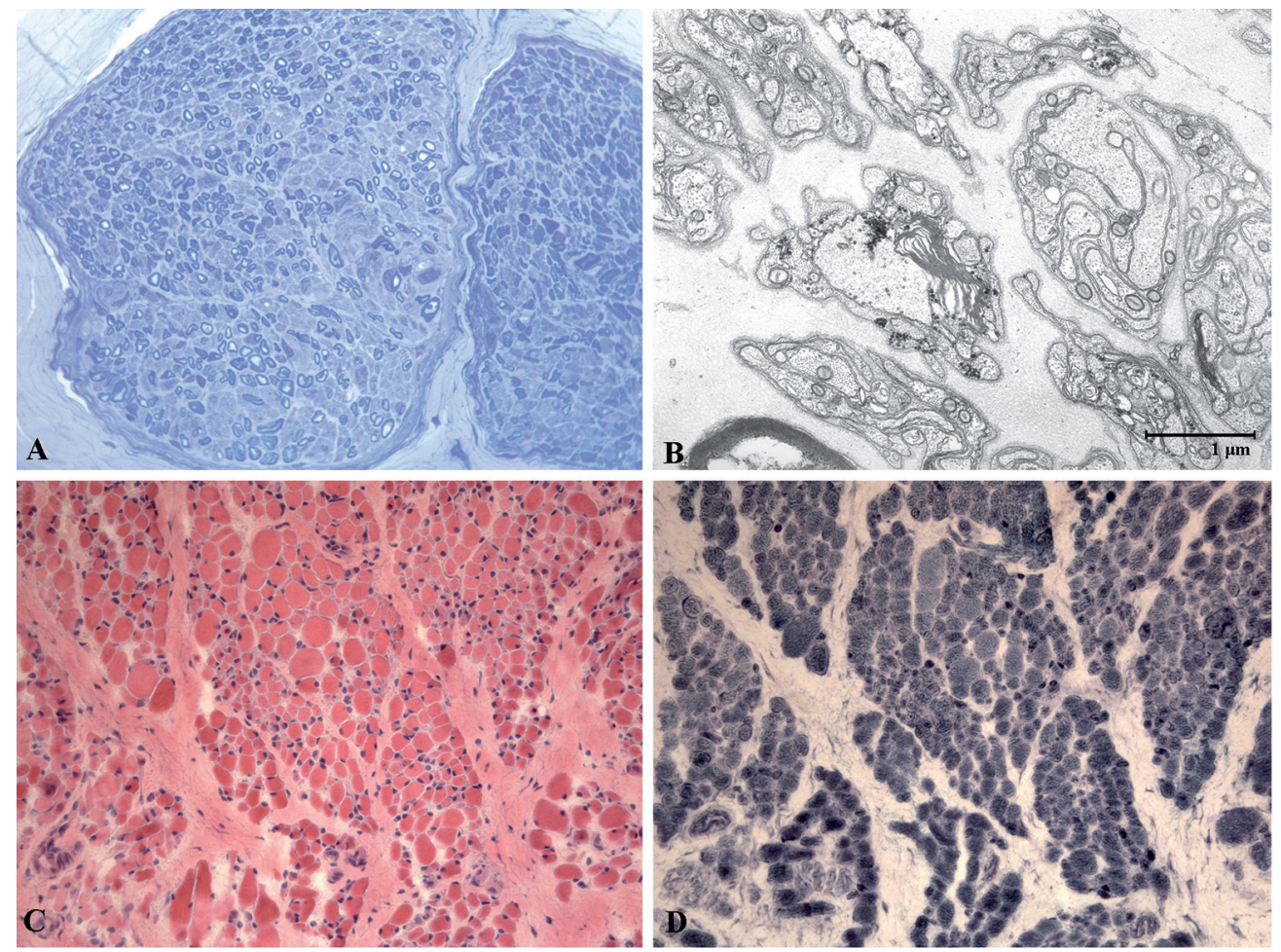

Figure 1. A: Semithin section of sural nerve biopsy at 5 months of age showing marked reduction of myelinated fiber density and endoneurial fibrosis, without onion bulbs, axonal sprouting, or inflammatory infiltrates. (Toluidine blue 200x). B: Demyelinated axons and Schwann cells arranged into bands of Büngner under electron microscopy examination of the sural nerve sample at 5 months. C: Muscle biopsy at 10 months of age (H \& E 200x). Note marked peri and endomysial fibrosis and fatty infiltration with groups of small fibers and scattered hypertrophic fibers. D: NADH staining showing atrophic fibers with increased oxidative activity (NADH 200x).
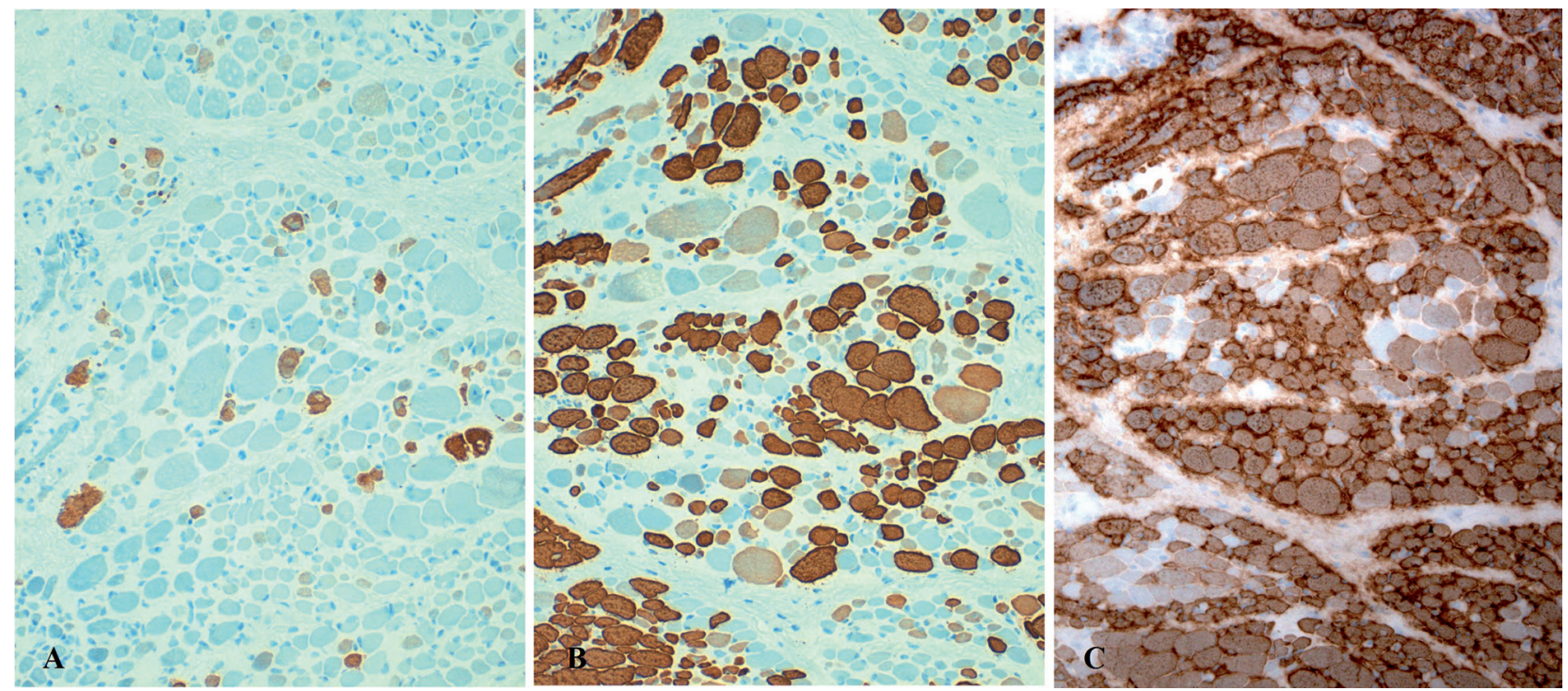

Figure 2. Immunohistochemical expression of developmental (dMHC), slow (sMHC), and fast (fMHC) myosin heavy chains in muscle biopsy at 10 months of age showing features of immature fetal phenotype. A: Developmental myosin predominates in atrophic and a few hypertrophic fibers (dMHC 200x). B: Slow HC myosin: hypertrophic fibers are characterized by their predominant expression; atrophic fibers also express slow HC. C: Fast MHC: atrophic fibers.

end stage of the disease, tracheostomy and gastrostomy were required, and the baby developed recurrent pulmonary, urinary, and systemic infections. Autonomic manifestations subsequently occurred, including neurogenic bladder and cardiac arrhythmia. The 

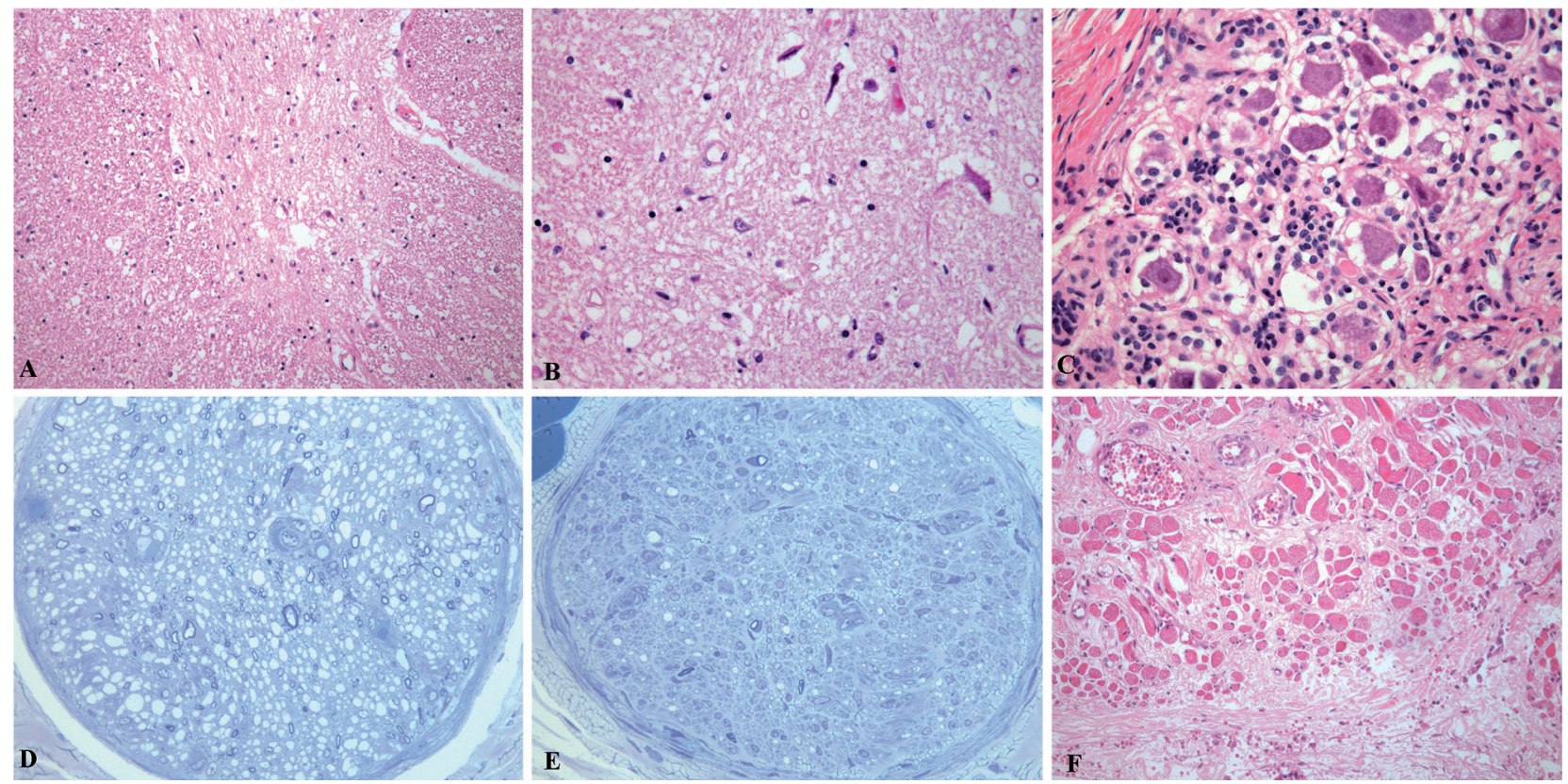

Figure 3. Post-mortem findings: A: Anterior horn of the spinal cord showing atrophy and significant reduction of motor neurons (H \& E 200x). B: The remaining neurons presented chromatolysis and pyknosis (H \& E 400x). C: Dorsal root ganglia with marked neuronal loss and abundant clusters of satellite cells' nuclei (Nageotte nodules) (H \& E 200x). D; E: Semithin sections. Remarkable nerve damage in sural and sciatic nerves, respectively, consisting of massive loss of myelinated fibers without signs of axonal regeneration or remyelination (Toluidine blue 100x). F: Severe fiber atrophy, fibrosis, and infiltration of diaphragmatic muscle sample (H \& E 200×).

child died of respiratory failure at 23 months of age. Permission to perform a necropsy was obtained.

Post-mortem examination revealed bilateral pneumonic consolidation and pleural effusion. The spinal cord showed a reduced anterior spinal root diameter and prominent loss of motor neurons in the anterior horns (Figure 3A), extending from the cervical to the lumbar region. The remaining motor neurons displayed chromatolysis and pyknosis (Figure 3B). In DRG, significant neuronal loss was observed (Figure 3C), better depicted with S100 immunohistochemistry. The overall size of nerve cells was small with abundant clusters of satellite cells' nuclei (Nageotte nodules). No abnormalities were present in the brain and midbrain motor nuclei.

Severe axonal depletion was found in sural (Figure 3D) and sciatic (Figure 3E) nerve samples, with less than $50-60 \%$ of preserved fibers and prominent endoneurial fibrosis. Fibers showed thin myelin sheaths without signs of active demyelination or remyelination. Non-myelinated fibers were morphologically normal and basal lamina did not show abnormalities. Onion bulbs, axonal sprouts, or inflammatory infiltrates were absent.

Muscle samples from the limbs, diaphragm, and intercostal muscles showed large groups of atrophic fibers with frequent nuclear clumps, massive adipose infiltration, and fibrosis, particularly in the diaphragm (Figure 3F).

Further genetic studies were performed. Automatic sequencing of all 15 exons and flanking regions of $I G H M B P 2$ on $11 \mathrm{q} 13-\mathrm{q} 21$ revealed a compound heterozygous mutation R147X/C496X ([4], case no. 15). These mutations were demonstrated in the father and the mother respectively.

Some years later, the mother became pregnant and underwent prenatal diagnostic tests in a chorionic villi biopsy at 11 weeks' gestation, with her written informed consent. Prenatal molecular analysis in DNA extracted from chorionic villi samples proved the second fetus to be single heterozygote, harboring the paternal mutation. The pregnancy was continued, and a healthy girl was born at term and remains unaffected at 5 years of age. 
Table 2. Clinical and histopathological findings.

\begin{tabular}{|c|c|c|}
\hline & \begin{tabular}{|l|} 
Porro et al., 2014 [13] \\
(Review $1974-2014$ )
\end{tabular} & San Millán et al \\
\hline Cases & 127 & Case report \\
\hline $\begin{array}{l}\text { Onset of respiratory } \\
\text { symptoms }\end{array}$ & From birth -3.5 years & $\begin{array}{l}\text { First episode: at birth } \\
\text { Second episode: } 3 \text { months }\end{array}$ \\
\hline Age of death & 1 hour -5 years & 23 months \\
\hline Prenatal symptoms & $\begin{array}{l}\text { None } \\
\text { IUGR, Prematurity } \\
\text { Low birth weight } \\
\text { Oligohydramnios }\end{array}$ & $\begin{array}{l}\text { IUGR } \\
\text { Decreased fetal movements } \\
\text { Abruptio placentae } \\
\text { Low birth weight }\end{array}$ \\
\hline $\begin{array}{l}\text { Diaphragmatic } \\
\text { involvement }\end{array}$ & $\begin{array}{l}\text { Diaphragmatic paralysis: } \\
\text { - Eventration in imaging } \\
\text { - Right hemidiaphragm involvement } \\
\text { - Respiratory weakness and recurrent pulmonary } \\
\text { infections }\end{array}$ & $\begin{array}{l}\text { Diaphragmatic paralysis: } \\
\text { - Eventration on chest X-Ray and electromyopgraphy } \\
\text { - Left hemidiaphragm involvement } \\
\text { - Bronchiolitis } \\
\text { - Death from pneumonia }\end{array}$ \\
\hline $\begin{array}{l}\text { Neuromuscular } \\
\text { features }\end{array}$ & $\begin{array}{l}\text { Hypotonia, areflexia, lingual fasciculations, weak cry, } \\
\text { proximal and distal limb weakness, ankle and knee joint } \\
\text { contractures, pes equinus, foot deformities, axonal } \\
\text { sensory-motor neuropathy }\end{array}$ & $\begin{array}{l}\text { Hypotonia, areflexia, weak cry, limb weakness with } \\
\text { predominant distal involvement, pes equinovarus, } \\
\text { Achilles and finger contractures, axonal sensory-motor } \\
\text { neuropathy }\end{array}$ \\
\hline $\begin{array}{l}\text { CNS sensorial and } \\
\text { autonomic }\end{array}$ & $\begin{array}{l}\text { Cognitive dysfunction, language dysfunction, hyperten- } \\
\text { sion, urinary retention, feeding difficulties, dysphagia, } \\
\text { slow peristalsis, arrhythmia, sweating, seizures, } \\
\text { cardiovascular collapse }\end{array}$ & $\begin{array}{l}\text { Neurogenic bladder } \\
\text { Cardiac arrhythmia }\end{array}$ \\
\hline Neuropathology & $\begin{array}{l}\text { Spinal cord: } \\
\text { - Degeneration and loss of anterior horn cells, atrophy } \\
\text { of the nerve roots } \\
\text { Skeletal muscle: } \\
\text { - Neurogenic atrophy (limbs and diaphragm) } \\
\text { Peripheral nerves: } \\
\text { - Axonal degeneration and atrophy }\end{array}$ & $\begin{array}{l}\text { Spinal cord: } \\
\text { - Degeneration and loss of anterior horn cells, atrophy } \\
\text { of nerve roots } \\
\text { - Neuronal loss in dorsal root ganglia, Nageotte nodules } \\
\text { Skeletal muscles (limbs, diaphragm, intercostal): } \\
\text { - Severe neurogenic atrophy, particularly in the } \\
\text { diaphragm } \\
\text { Peripheral nerves: } \\
\text { - Severe axonal depletion in sural and sciatic nerves, } \\
\text { endoneurial fibrosis, thin myelin sheaths }\end{array}$ \\
\hline
\end{tabular}

\section{Discussion}

SMARD1 is characterized by degeneration of anterior horn spinal motor neurons, leading to rapidly progressive neurogenic muscular atrophy of limbs and diaphragm [3]. Neurons on the DRG also degenerate, leading to an axonal neuronopathy, whereas involvement of the cranial nerves has only been reported in advanced cases [4]. Phenotype variability has been described even in siblings with identical mutations [10], and prenatal manifestations are not uncommon including IUGR, prematurity, and decreased fetal movements [11, 12]. An exhaustive clinicopathological review of 125 SMARD1 cases has been recently reported [13]. Our data, compared to those previously reported, are shown on Table 2.

Some cases show early feeding difficulties or weak cry, but respiratory distress is the most common presenting feature. SMARD1 phenotype may be broader than initially considered $[2,10,13]$, and few cases with milder phenotype and no evidence of diaphragmatic involvement until 4 years of age have been reported [2]. Respiratory distress resulting from irreversible phrenic denervation requires mechanical ventilation from early stages until death, which usually occurs in the first years of life. Unusual prolonged survival has been reported in some patients upon mechanical ventilation (from 4.5 to 21 years of age) due to exemplary care $[14,15]$.

Phrenic paralysis can be demonstrated on chest X-ray as diaphragmatic eventration and by electrophysiological studies, as in the present case. Plication of the diaphragm has been performed in several patients without success [16], and to date there is no effective drug therapy. At present, stem cell transplantation and gene therapy represent a potentially useful treatment strategy to ameliorate the SMARD1 phenotype [17, 18].

The child herein reported suffered her first respiratory distress episode early after 
birth, requiring mechanical ventilation. After the second episode, at 3 months of age, she remained ventilator-dependent until death at age 23 months. Diaphragmatic paralysis was demonstrated on the left hemidiaphragm by electrophysiological examination. Curiously, SMARD1 patients reported so far exhibited predominant right phrenic involvement, probably resulting from the pressure effect caused by the liver $[13,16]$.

Distal limb weakness, progressive generalized hypotonia, and foot deformities appeared after respiratory insufficiency. Quadriplegia, finger contractures, and fatty pads on the proximal phalanges resulting from adipose tissue infiltration, subsequently developed $[4,12,19]$.

In addition to motor neuron involvement, neurons in the DRG are also involved in SMARD1, causing axonal sensory neuronopathy with distal to proximal progression. Significant neuronal loss and residual nodules of Nageotte at sites of destroyed neurons were clearly demonstrated in DRG at post-mortem examination.

Corresponding to the clinical features, progressive loss of response for motor and sensory conduction velocities was observed, leading to an absent response after maximum stimulation in the end stage of the disease.

Autonomic nervous system involvement is well documented in SMARD1, including excessive sweating, constipation, cardiac rhythm abnormalities, or sphincter control dysregulation $[12,20]$. In the present case, cardiac arrhythmia and neurogenic bladder appeared late in the course of the disease.

Pre- and post-mortem histopathological findings in nerves and muscles demonstrated the progression over time of SMARD1. Muscle biopsy at 5 months of age was considered normal, in contrast to significant loss of myelinated fibers observed in sural biopsy. A considerable degree of muscle involvement was noted at 10 months, with definite signs of neurogenic atrophy without signs of reinnervation.

A marked progression of muscle damage was present in post-mortem samples, with the most severe damage in the diaphragm.

Peripheral motor and sensory nerves were severely involved and the histopathological picture was most likely due to a primary axonal disorder, as there were no signs of demyelination/remyelination or onion bulb formation and the myelin in the remaining fibers was of normal thickness. There was no evidence of hypomyelination, thus excluding the diagnosis of congenital amyelinating or demyelinating neuropathy [21, 22, 23]. The spinal cord exhibited extensive loss of motor neurons in the anterior horns and DRG showed a marked reduction of ganglionic cells.

Differential diagnosis of SMARD1 includes disorders displaying acute, early respiratory insufficiency and other causes of floppy infant syndrome. Some children were reported to have died from acute respiratory infection or sudden infant death syndrome $[7,24]$. The main differential diagnosis should be established with SMARD2, a rare $\mathrm{X}$-linked disorder with SMARD phenotype and mutations in LASIL (ORPHA404521) [25]. Other possible diagnoses include SMA1 (Werdnig-Hoffmann disease). In contrast to SMARD1, proximal muscle weakness is the presenting sign of SMA1, and the respiration is compromised due to intercostal muscle involvement, as the disease progresses, causing paradoxical breathing and a bell-shaped thorax deformity. SMARD1 early involves phrenic muscle, without causing thoracic deformities. Peripheral sensory neuropathy, a hallmark of SMARD1, is not typically present in SMA1, although isolated cases have been reported [26]. Both SMA and SMARD1 children have normal intelligence and remain alert and attentive.

Other causes of floppy infant syndrome must be considered, including glycogenosis type II (Pompe disease), or congenital myopathies (CM) with usually distinctive histopathological features. Congenital myotonic dystrophy type 1 presents with pronounced myopathic typical facies, arthrogryposis, and familial history [27]. Neonatal myasthenia gravis and congenital forms of myasthenic syndrome must be excluded, based on electromyographic findings and familial history. The lesional topography and fatal course of the disease in this patient were not suggestive of other disorders such as arthrogryposis multiplex congenita.

IGHMBP2 is a ubiquitous ribosomeassociated enzyme, that functions as a 5'-3' RNA/DNA helicase [28]. The cellular pathomechanisms that result from IGHMBP2 gene mutations are not well un- 
derstood. Pathogenesis of motor neuron diseases as a group could be related with RNA metabolism [29]. IGHMBP2 and LAS1L, both resulting in SMARD phenotypes, have roles in ribosomal biogenesis via processing of the 45S pre-rRNA [25]. However, a direct interaction between them has not been demonstrated [25].

In conclusion, we describe the neuropathological and electrophysiological findings of a Spanish patient with SMARD1, one of the more detailed cases with follow-up studies and post-mortem examination. The diagnosis of SMARD1, a more frequent disorder than suspected, should be considered in children with early respiratory insufficiency or in cases of atypical spinal muscular atrophy, even in the absence of overt diaphragmatic weakness [10]. SMARD1 diagnosis is of particular importance as it allows accurate genetic counselling and assists in the decision-making process for the initiation of mechanical ventilation of an affected infant [30]. Direct sequencing of the IGHMBP2 gene should be performed if clinical and neuropathological features are compatible and SMN1 mutation studies have been negative. Cases with normal IGHMBP2 study should be screened for $L A S 1 L$ mutations. Genetic counselling and prenatal diagnosis should be offered to all families with a familial history of SMARD1 in order to discuss the options and risks.

\section{Acknowledgment}

We thank Tania Vazquez-Santos, Cristina Vazquez-Santos, and Soraya Barrera for technical assistance. This work was supported in part by Grants from the "Instituto de Salud Carlos III, ISCIII" (PI10/02628 and RD09/0076/00011); Xunta de Galicia (REGENPSI-2009/013) and by European Union funded projects Spain-RDR "Spanish Rare Disease Registries Research Network" (IRDiRC) and BIOCAPS (FP7/REGPOT-2012-2013.1, agreement no 316265).

\section{Conflict of interests}

The authors declare no conflict of interest.

\section{References}

[1] Mellins RB, Hays AP, Gold AP, Berdon WE, Bowdler $J D$. Respiratory distress as the initial manifestation of Werdnig-Hoffmann disease. Pediatrics. 1974; 53: 33-40. PubMed

[2] Grohmann K, Wienker TF, Saar K, RudnikSchöneborn S, Stoltenburg-Didinger $G$, Rossi R, Novelli G, Nürnberg G, Pfeufer A, Wirth B, Reis $A$, Zerres $K$, Hübner $C$. Diaphragmatic spinal muscular atrophy with respiratory distress is heterogeneous, and one form Is linked to chromosome 11q13-q21. Am J Hum Genet. 1999; 65: 1459-1462. CrossRef PubMed

[3] Grohmann K, Schuelke M, Diers A, Hoffmann K, Lucke B, Adams C, Bertini E, Leonhardt-Horti $H$, Muntoni F, Ouvrier R, Pfeufer A, Rossi R, Van Maldergem L, Wilmshurst JM, Wienker TF, Sendtner M, Rudnik-Schöneborn S, Zerres K, Hübner $C$. Mutations in the gene encoding immunoglobulin mu-binding protein 2 cause spinal muscular atrophy with respiratory distress type 1 . Nat Genet. 2001; 29: 75-77. CrossRef PubMed

[4] Grohmann K, Varon R, Stolz P, Schuelke M, Janetzki C, Bertini E, Bushby K, Muntoni F, Ouvrier $R$, Van Maldergem L, Goemans NM, Lochmüller H, Eichholz S, Adams C, Bosch F, Grattan-Smith P, Navarro C, Neitzel H, Polster T, Topaloğlu H, et al. Infantile spinal muscular atrophy with respiratory distress type 1 (SMARD1). Ann Neurol. 2003; 54: 719-724. CrossRef PubMed

[5] Guenther UP, Schuelke M, Bertini E, D'Amico A, Goemans N, Grohmann K, Hübner C, Varon $R$. Genomic rearrangements at the IGHMBP2 gene locus in two patients with SMARD1. Hum Genet. 2004; 115: 319-326. CrossRef PubMed

[6] Guenther UP, Varon R, Schlicke M, Dutrannoy V, Volk A, Hübner C, von Au K, Schuelke M. Clinical and mutational profile in spinal muscular atrophy with respiratory distress (SMARD): defining novel phenotypes through hierarchical cluster analysis. Hum Mutat. 2007; 28: 808-815. CrossRef PubMed

[7] Bertini E, Gadisseux JL, Palmieri G, Ricci E, Di Capua M, Ferriere G, Lyon G. Distal infantile spinal muscular atrophy associated with paralysis of the diaphragm: a variant of infantile spinal muscular atrophy. Am J Med Genet. 1989; 33: 328-335. CrossRef PubMed

[8] Novelli G, Capon F, Tamisari L, Grandi E, Angelini C, Guerrini P, Dallapiccola B. Neonatal spinal muscular atrophy with diaphragmatic paralysis is unlinked to 5q11.2-q13. J Med Genet. 1995; 32: 216-219. CrossRef PubMed

[9] Basel-Vanagaite L, Taub E, Drasinover V, Magal $N$, Brudner A, Zlotogora J, Shohat M. Genetic carrier screening for spinal muscular atrophy and spinal muscular atrophy with respiratory distress 1 in an isolated population in Israel. Genet Test. 2008; 12: 53-56. CrossRef PubMed

[10] Joseph S, Robb SA, Mohammed S, Lillis S, Simonds A, Manzur AY, Walter $S$, Wraige E. Interfamilial phenotypic heterogeneity in SMARD1. Neuromuscul Disord. 2009; 19: 193-195. CrossRef PubMed

[11] Kaindl AM, Guenther UP, Rudnik-Schöneborn S, Varon R, Zerres K, Schuelke M, Hübner C, von Au $K$. Spinal muscular atrophy with respiratory dis- 
tress type 1 (SMARD1). J Child Neurol. 2008; 23: 199-204. CrossRef PubMed

[12] Eckart M, Guenther UP, Idkowiak J, Varon $R$ Grolle B, Boffi P, Van Maldergem L, Hübner C, Schuelke $M$, von $A u K$. The natural course of infantile spinal muscular atrophy with respiratory distress type 1 (SMARD1). Pediatrics. 2012; 129: e148-e156. CrossRef PubMed

[13] Porro F, Rinchetti P, Magri F, Riboldi G, Nizzardo $M$, Simone C, Zanetta C, Faravelli I, Corti S. The wide spectrum of clinical phenotypes of spinal muscular atrophy with respiratory distress type 1 : a systematic review. J Neurol Sci. 2014; 346: 35-42. CrossRef PubMed

[14] Pierson TM, Tart G, Adams D, Toro C, Golas G, Tifft $C$, Gahl $W$. Infantile-onset spinal muscular atrophy with respiratory distress-1 diagnosed in a 20-year-old man. Neuromuscul Disord. 2011; 21: 353-355. CrossRef PubMed

[15] Hamilton MJ, Longman C, O'Hara A, Kirkpatrick $M, M c W i l l i a m R$. Growing up with spinal muscular atrophy with respiratory distress (SMARD1). Neuromuscul Disord. 2015; 25: 169-171. CrossRef PubMed

[16] Kaindl AM, Guenther UP, Rudnik-Schöneborn S, Varon R, Zerres K, Gressens P, Schuelke M, Hubner $C$, von $A u K$. [Distal spinal-muscular atrophy 1 (DSMA1 or SMARD1)]. Arch Pediatr. 2008; 15: 1568-1572. CrossRef PubMed

[17] van der Pol WL, Talim B, Pitt M, von Au K. 190 th ENMC international workshop: Spinal muscular atrophy with respiratory distress/distal spinal muscular atrophy type 1: 11-13 May 2012, Naarden, The Netherlands. Neuromuscul Disord. 2013; 23: 602-609. CrossRef PubMed

[18] Simone C, Nizzardo M, Rizzo F, Ruggieri M, Riboldi $G$, Salani S, Bucchia M, Bresolin N, Comi $G P$, Corti $S$. iPSC-Derived neural stem cells act via kinase inhibition to exert neuroprotective effects in spinal muscular atrophy with respiratory distress type 1. Stem Cell Rep. 2014; 3: 297-311. CrossRef PubMed

[19] Rudnik-Schöneborn S, Stolz P, Varon R, Grohmann $K$, Schächtele $M$, Ketelsen UP, Stavrou D, Kurz H, Hübner C, Zerres $K$. Long-term observations of patients with infantile spinal muscular atrophy with respiratory distress type 1 (SMARD1). Neuropediatrics. 2004; 35: 174-182. CrossRef PubMed

[20] Mohan U, Misra VP, Britto J, Muntoni F, King $R H$, Thomas $P K$. Inherited early onset severe axonal polyneuropathy with respiratory failure and autonomic involvement. Neuromuscul Disord. 2001; 11: 395-399. CrossRef PubMed

[21] Simonati A, Fabrizi GM, Pasquinelli A, Taioli F, Cavallaro T, Morbin M, Marcon G, Papini M, Rizzuto $N$. Congenital hypomyelination neuropathy with Ser72Leu substitution in PMP22. Neuromuscul Disord. 1999; 9: 257-261. $\underline{\text { CrossRef }}$ PubMed

[22] Warner LE, Mancias P, Butler IJ, McDonald CM, Keppen L, Koob KG, Lupski JR. Mutations in the early growth response 2 (EGR2) gene are associated with hereditary myelinopathies. Nat Genet. 1998; 18: 382-384. CrossRef PubMed

[23] Mandich P, Mancardi GL, Varese A, Soriani S, Di Maria E, Bellone E, Bado M, Gross L, Windebank AJ, Ajmar F, Schenone A. Congenital hypomy- elination due to myelin protein zero Q215X mutation. Ann Neurol. 1999; 45: 676-678. CrossRef PubMed

[24] Bove KE, Iannaccone ST. Atypical infantile spinomuscular atrophy presenting as acute diaphragmatic paralysis. Pediatr Pathol. 1988; 8: 95-107. CrossRef PubMed

[25] Butterfield RJ, Stevenson TJ, Xing L, Newcomb TM, Nelson B, Zeng W, Li X, Lu HM, Lu H, Farwell Gonzalez KD, Wei JP, Chao EC, Prior TW, Snyder PJ, Bonkowsky JL, Swoboda KJ. Congenital lethal motor neuron disease with a novel defect in ribosome biogenesis. Neurology. 2014; 82: 1322-1330. CrossRef PubMed

[26] Rudnik-Schöneborn S, Goebel HH, Schlote W, Molaian S, Omran H, Ketelsen U, Korinthenberg $R$, Wenzel D, Lauffer H, Kreiss-Nachtsheim M, Wirth B, Zerres K. Classical infantile spinal muscular atrophy with SMN deficiency causes sensory neuronopathy. Neurology. 2003; 60: 983-987. CrossRef PubMed

[27] Harper PS, Monckton DG. Myotonic dystrophy. In: Engel AG, Franzini-Amstrong (eds). Myology. New York: McGraw-Hill, 2004. p. 1039-1076.

[28] Guenther UP, Handoko L, Laggerbauer B, Jablonka S, Chari A, Alzheimer M, Ohmer J, Plöttner O, Gehring N, Sickmann A, von Au K, Schuelke M, Fischer U. IGHMBP2 is a ribosomeassociated helicase inactive in the neuromuscular disorder distal SMA type 1 (DSMA1). Hum Mol Genet. 2009; 18: 1288-1300. CrossRef PubMed

[29] Bertini E, Houlden H. Defects of RNA metabolism in the pathogenesis of spinal muscular atrophy. Neurology. 2014; 82: 1298-1299. CrossRef PubMed

[30] Sangiuolo F, Filareto A, Giardina E, Nardone AM, Pilu G, Pietropolli A, Bertini E, Novelli G. Prenatal diagnosis of spinal muscular atrophy with respiratory distress (SMARD1) in a twin pregnancy. Prenat Diagn. 2004; 24: 839-841. CrossRef PubMed 